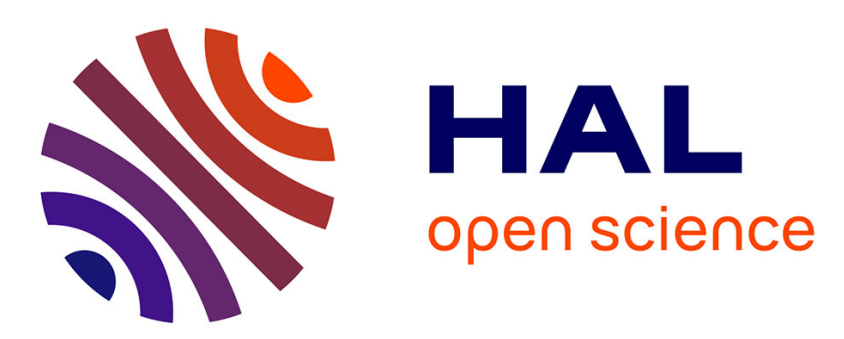

\title{
3-Alkoxy-4-bromothiophenes: general synthesis of monomers and regio-selective preparation of two dimers
}

Gurunathan Savitha, Noémie Hergué, E. Guilmet, Magali Allain, Pierre Frère

\section{To cite this version:}

Gurunathan Savitha, Noémie Hergué, E. Guilmet, Magali Allain, Pierre Frère. 3-Alkoxy-4bromothiophenes: general synthesis of monomers and regio-selective preparation of two dimers. Tetrahedron Letters, 2011, 52 (12), pp.1288-1291. 10.1016/j.tetlet.2011.01.050 . hal-03344598

\section{HAL Id: hal-03344598 \\ https://univ-angers.hal.science/hal-03344598}

Submitted on 15 Sep 2021

HAL is a multi-disciplinary open access archive for the deposit and dissemination of scientific research documents, whether they are published or not. The documents may come from teaching and research institutions in France or abroad, or from public or private research centers.
L'archive ouverte pluridisciplinaire HAL, est destinée au dépôt et à la diffusion de documents scientifiques de niveau recherche, publiés ou non, émanant des établissements d'enseignement et de recherche français ou étrangers, des laboratoires publics ou privés. 
Provided for non-commercial research and education use. Not for reproduction, distribution or commercial use.

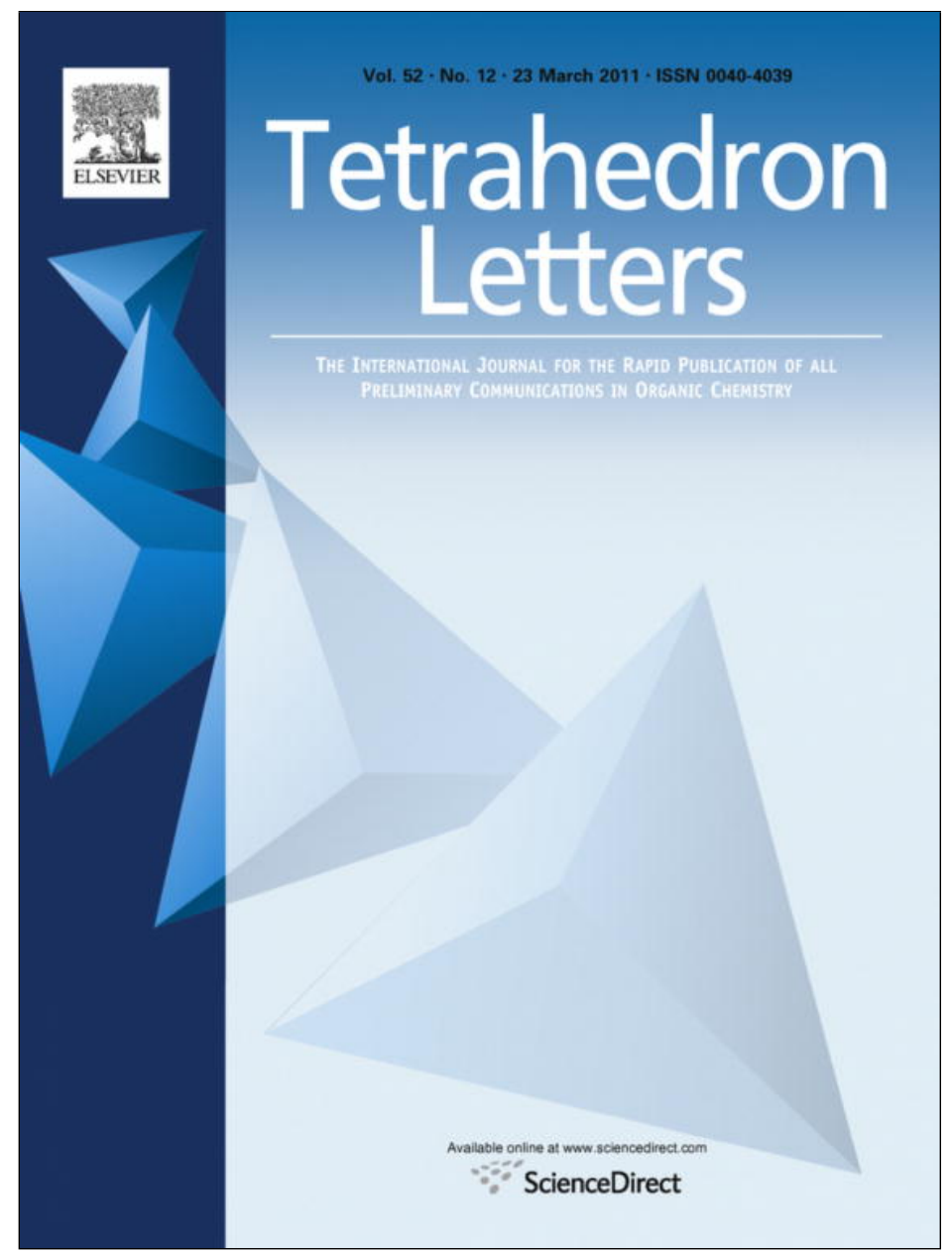

This article appeared in a journal published by Elsevier. The attached copy is furnished to the author for internal non-commercial research and education use, including for instruction at the authors institution and sharing with colleagues.

Other uses, including reproduction and distribution, or selling or licensing copies, or posting to personal, institutional or third party websites are prohibited.

In most cases authors are permitted to post their version of the article (e.g. in Word or Tex form) to their personal website or institutional repository. Authors requiring further information regarding Elsevier's archiving and manuscript policies are encouraged to visit:

http://www.elsevier.com/copyright 


\title{
3-Alkoxy-4-bromothiophenes: general synthesis of monomers and regio-selective preparation of two dimers
}

\author{
Gurunathan Savitha, Noémie Hergué, Erwan Guilmet, Magali Allain, Pierre Frère* \\ University of Angers, MOLTECH-Anjou, UMR CNRS 6200, Group Linear Conjugated Systems, 2 Bd Lavoisier, 49045 Angers, France
}

\section{A R T I C L E I N F O}

\section{Article history:}

Received 13 October 2010

Revised 4 January 2011

Accepted 12 January 2011

Available online 18 January 2011

\begin{abstract}
A B S T R A C T
3-Alkoxy-4-bromothiophenes were synthesized in three steps from the readily available methyl 2-carboxylate-3-hydroxythiophene and two isomers of bithiophenes based on the 3-bromo-4-methoxythiophene moiety were regio-selectively prepared.
\end{abstract}

(c) 2011 Elsevier Ltd. All rights reserved.

\section{Keywords:}

Alkoxythiophene

Bromothiophene

Bithiophenes

S. . O interactions

Functionalized thiophenes on the 3 and 4 positions are attractive building blocks for the development of materials based on $\pi$ conjugated systems usable as organic semiconductors in electronic or optoelectronic devices or as electrode materials for sensors. ${ }^{1-7}$ In this field, the attachment of alkoxy groups to $\beta$-positions of thiophene rings has emerged as a solution for developing polymers with moderate bandgap, low oxidation potential, and good stability of the conducting oxidized state. ${ }^{8}$ 3-Alkoxythiophene derivatives are usually prepared from 3-bromothiophene by the aromatic nucleophilic substitution with alcoholate anion catalyzed by $\mathrm{Cu}(\mathrm{I})$ halide. ${ }^{9}$ More recently a transetherification reaction from 3-methoxythiophene has allowed the preparation of various alkoxythiophene derivatives. ${ }^{3,5}$ Efficient synthesis of 3,4-dialkoxythiophenes was also described from ethyl 3,4-dihydroxy-2,5-thiophene-dicarboxylate obtained in one step by the condensation between diethyl malonate and diethylthiodiglycolate, or from 3,4-dimethoxythiophene by the transetherification reaction. ${ }^{10,11}$

Cihaner and Onal reported the synthesis of 3-bromo-4-methoxythiophene in $70 \%$ yield by the reaction of methanolate anion on 3,4-dibromothiophene in the presence of $\mathrm{CuO}$ and $\mathrm{KI}^{12}$ However, this protocol suffers from various drawbacks. Firstly 3,4-dibromothiophene is an expensive starting material, which is synthesized in two steps from thiophene. ${ }^{13,14}$ Secondly the procedure requires a long reaction time of about 3 days. We recently reported that the reaction time can be effectively reduced to 30 min by carrying out the reaction in microwave. ${ }^{15}$ Although convenient for the preparation of 3-bromo-4-methoxythiophene, this

\footnotetext{
* Corresponding author.

E-mail address: pierre.frere@univ-angers.fr (P. Frère).
}

method is not adapted for grafting longer or branched alkoxy chains. Thus attempts with alcoholate anion of hexan-1-ol or 2ethylhexan-1-ol gave yields inferior to $5 \%$.

As part of our research aimed in the development of new synthetic routes to substituted thiophenes, we have been developing the access to alkoxythiophene derivatives from easily available starting materials. We recently reported the synthesis of 3,4-dialkoxythieno[2,3-b]thiophenes, ${ }^{16}$ 3,6-dialkoxythieno[3,2$b]$ thiophenes, ${ }^{17}$ and 3 -substituted thieno[3,2-b]furanes ${ }^{18}$ from $\beta$ hydroxythiophene derivatives. As continuation in this approach, we herein report a straightforward and general procedure for the synthesis of 3-alkoxy-4-bromothiophene derivatives from the readily accessible methyl 2-carboxylate-3-hydroxythiophene. The selective synthesis of two regioisomers of dimers, namely 3,3'-dibromo-4,4'-dimethoxy-2,2'-bithiophene and 4,4'-dibromo-3,3'dimethoxy-2,2'-bithiophene is also described.

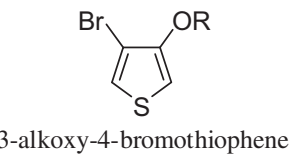

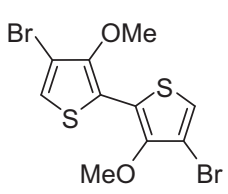

4,4'-dibromo-3,3'-dimethoxy2,2'-bithiophene

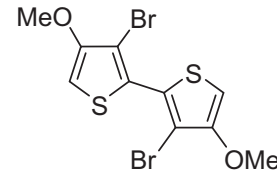

3,3'-dibromo-4,4'-dimethoxy2,2'-bithiophene 


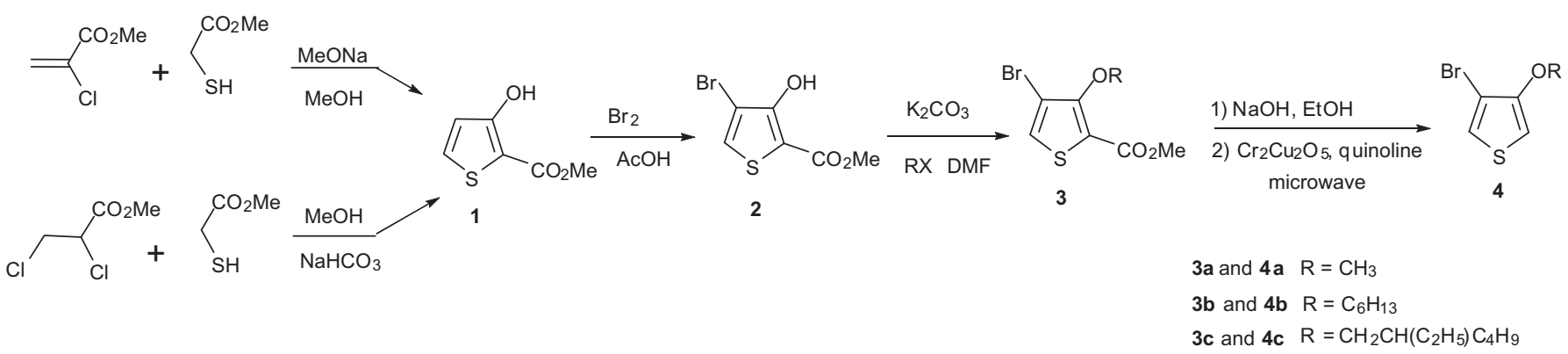

Scheme 1.

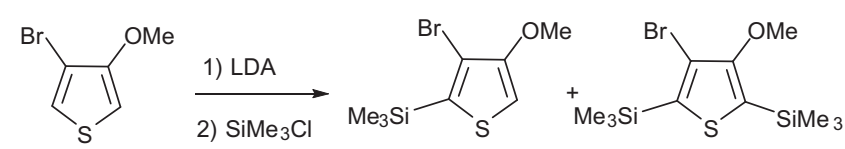

$4 a$

5

6<smiles>COc1csc(-c2scc(Br)c2OC)c1-c1scc(Br)c1OC</smiles>

Scheme 2 .

The 3-alkoxy-4-bromothiophene derivatives were prepared in four steps from 2-carboxylate-3-hydroxythiophene $\mathbf{1}$ according to Scheme 1 . The last can be easily obtained by the action of thiolate anion of methyl thioglycolate on the methyl chloroacrylate as described by Huddleston and Barker. ${ }^{19}$ Interestingly the commercially available economically viable 2,3 -dichloro propionate, which generates in situ methyl chloroacrylate by using an excess of sodium hydrogenocarbonate ${ }^{20}$ can be also used in a simple protocol in methanol. The regioselective bromination of compound $\mathbf{1}$ was carried out by treating with 1 equiv of bromine in acetic acid to give compound $\mathbf{2}$ in 76\% yield. ${ }^{21}$ The O-alkylation of compound $\mathbf{2}$ was carried out with alkylating reagents, such as methyl iodide, 1-bromohexane, or 1-bromo-2-ethylhexane in the presence of $\mathrm{K}_{2} \mathrm{CO}_{3}$ as base in DMF to give corresponding alkoxy derivatives 3 in $70-80 \%$ yields. Finally, decarboxylation of the acid resulting from the saponification of compounds 3 at $200{ }^{\circ} \mathrm{C}$ in quinoline

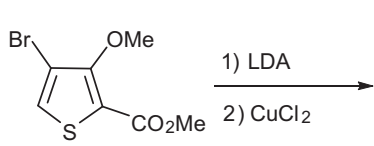

$3 a$

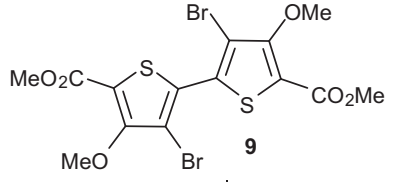

1) $\mathrm{NaOH}, \mathrm{EtOH}$

2) $\mathrm{Cr}_{2} \mathrm{Cu}_{2} \mathrm{O}_{5}$, quinoline microwave<smiles>COc1csc(-c2scc(OC)c2Br)c1Br</smiles>

under microwave irradiation in the presence of copper chromite gave the target molecule $\mathbf{4}$ in $70-75 \%$ yields for the two steps. ${ }^{22}$

We next focused our attention toward the synthesis of two regioisomers of bithiophene derivative from 3-bromo-4-methoxythiophene. Firstly lithiation of compound $\mathbf{4 a}$ was carried out by treating with 1.0-1.2 equiv of lithium diisopropylamide (LDA) followed by the treatment with chlorotrimethylsilane (Scheme 2). The reaction led to a mixture of mono $\mathbf{5}$ and di-silylated $\mathbf{6}$ derivatives in $60 \%$ and $22 \%$ yields, respectively. As revealed by ${ }^{1} \mathrm{H}$ NMR of compound $\mathbf{4 a}$, the difference between the chemical shifts of the two aromatic protons is an indication of their highly different acidity. The deshielding of proton adjacent to bromine atom $(7.18 \mathrm{ppm})$ is associated with a stronger acidity and the reaction with LDA allowed the deprotonation at 2-position. A second lithi-

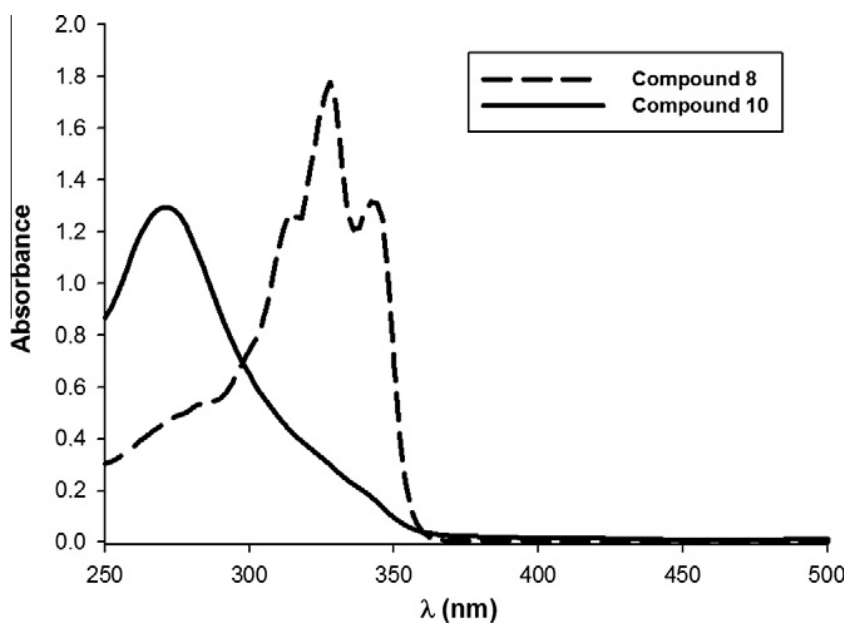

Figure 1. UV-vis. spectra of compounds $\mathbf{8}$ and $\mathbf{1 0}$ in $\mathrm{CH}_{2} \mathrm{Cl}_{2}$. 


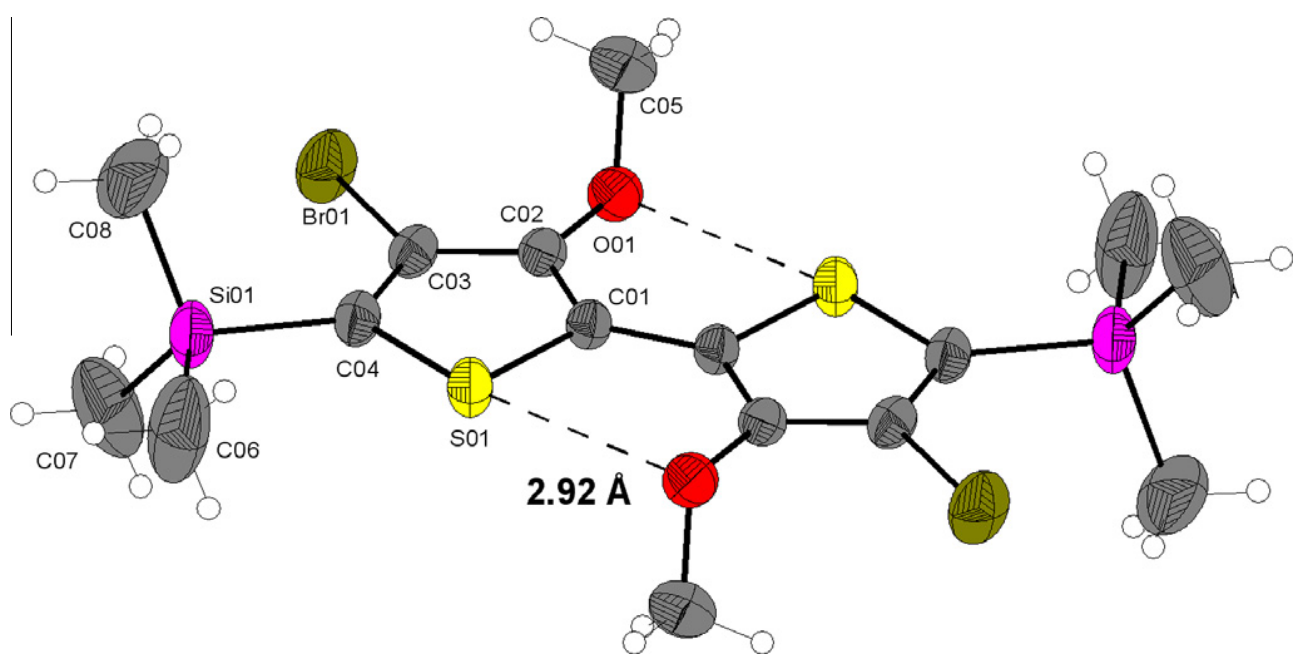

Figure 2. Ortep view of compound 7, ellipsoids drawn at 50\% probability level.

ation of $\mathbf{5}$ with LDA followed by the treatment with a slight excess of $\mathrm{CuCl}_{2}$ afforded bithiophene derivative $\mathbf{7}$ in $25 \%$ yield. Finally the treatment of $\mathbf{7}$ with fluorine anion led to the formation of one of the regioisomers of bithiophene $\mathbf{8}$ in $70 \%$ yield. $^{23}$

The synthesis of another regioisomer of bithiophene $\mathbf{1 0}$ with methoxy groups in the external positions was attempted by the direct copper catalyzed coupling reaction of the 2-lithio derivative of 4a, which afforded the target molecule only in 5\% yield. However, an alternate procedure for the synthesis of bithiophene $\mathbf{1 0}$ from compound 3a is depicted in Scheme 3. The treatment of 3a with 1 equiv of LDA and $\mathrm{CuCl}_{2}$ afforded bithiophene 9 in 55\%, which on further saponification and the decarboxylation reaction in quinoline in the presence of $\mathrm{Cr}_{2} \mathrm{Cu}_{2} \mathrm{O}_{5}$ upon microwave irradiation gave $\mathbf{1 0}$ in $30 \%$ yield. ${ }^{24}$ Compound $\mathbf{1 0}$ was found to be very sensitive to light and temperature and its stability was very low, which turned slowly to a dark brown solid in $1 \mathrm{~h}$ at room temperature after purification. However, we found that the solid was stable for several days when stored at $-20^{\circ} \mathrm{C}$ in dark.

The comparison of the UV-vis absorption spectra of compounds $\mathbf{8}$ and $\mathbf{1 0}$ revealed the predominant role of the relative position of the methoxy groups and bromine atoms on the conformation adopted by the two bithiophene isomers (Fig. 1). For compound 10 a structureless absorption band with a $\lambda_{\max }$ at $270 \mathrm{~nm}$ was observed whereas for isomer $\mathbf{8}$ a red shifted well resolved absorption band with a $\lambda_{\max }$ at $328 \mathrm{~nm}$ was observed. These marked differences indicate that derivative $\mathbf{8}$ with the methoxy groups in the internal position allows the conjugated systems to adopt more rigid and more planar structure. ${ }^{25}$ As already demonstrated for bithiophene derivatives substituted with alkoxy groups, the planar conformation is stabilized by $\mathrm{S} \ldots \mathrm{O}$ intramolecular interactions. ${ }^{8}$ In contrast the structures of bithiophenes substituted by bromine atoms at the 3 and $3^{\prime}$-positions are known to present a large torsion between the two thiophene rings. ${ }^{26}$

This was later supported by the results of X-ray diffraction studies of the single crystals of $\mathbf{7}$ obtained by slow evaporation from $\mathrm{CHCl}_{3}$ solution. ${ }^{27}$ As shown in Figure 2 the two thiophene cycles adopt a planar anti conformation with a dihedral angle inferior to $1^{\circ}$. The interatomic S-O distances of $2.92 \AA$ was found to be considerably shorter than the sum of the Van der Waals radii of sulfur and oxygen ( $3.35 \AA$ ), thus conforming the occurrence of non covalent S...O intramolecular interactions, which stabilize the planar conformation.

In conclusion, we have described a convenient and effective synthesis of 3-alkoxy-4-bromothiophene derivatives. Additionally the synthesis of two isomers of bithiophene, based on 3-bromo- 4-methoxythiophene moiety by playing on the regio selective synthesis of monosilylated derivative, was presented. The role of the relative position of the substituents on the thiophene moieties and its impact in the UV absorption spectra were also demonstrated. Further utilization of the synthesized 3-alkoxy-4-bromo thiophene in the synthesis of low band gap polymers is under progress in our laboratory.

\section{Acknowledgment}

We thank Région des Pays de la Loire for the financial support to G. Savitha for a postdoc position.

\section{Supplementary data}

Supplementary data (experimental data and copies of ${ }^{1} \mathrm{H}$ NMR and ${ }^{13} \mathrm{C}$ NMR of the new compounds) associated with this article can be found, in the online version, at doi:10.1016/j.tetlet. 2011.01.050.

\section{References and notes}

1. Barbarella, G.; Melucci, M.; Sotgiu, G. Adv. Mater. 2005, 17, 1581-1593.

2. Roncali, J. Macromol. Rapid. Commun. 2007, 28, 1761-1775.

3. For updated reviews on advanced functional polythiophenes based on tailored precursors, see: (a) Blanchard, P.; Leriche, P.; Frère, P.; Roncali, J. In Handbook of Conducting Polymers; Skotheim, T. A., Reynolds, J. R., Eds.; CRC Press: Boca Raton, 2007; Vol. 3, (b) Mishra, M.; Ma, C. Q.; Bäuerle, P. Chem. Rev. 2009, 109 1141-1276.

4. Ho, H. A.; Najari, A.; Leclerc, M. Acc. Chem. Res. 2008, 41, 168-178.

5. Ho, H. A.; Bera Aberem, M.; Leclerc, M. Chem. Eur. J. 2005, 11, 1718-1724.

6. Schulz, E.; Fahmi, K.; Lemaire, M. Acros Chim. Acta 1994, 1, 1-16.

7. Blanchard, P.; Jousselme, B.; Frère, P.; Roncali, J. J. Org. Chem. 2002, 67, 3961 3964.

8. Roncali, J.; Blanchard, P.; Frère, P. J. Mater. Chem. 2005, 15, 1589-1610.

9. Keegstra, M. A.; Peters, T. H.; Brandsma, L. Tetrahedron 1992, 48, 3633-3652.

10. Frontana-Uribe, B. A.; Heinze, J. Tetrahedron Lett. 2006, 47, 4635-4640.

11. von Kieseritzky, F.; Allared, F.; Dahstedt, E.; Hellberg, J. Tetrahedron Lett. 2004 $45,6049-6050$.

12. Cihaner, A.; Önal, A. M. J. Electroanal. Chem. 2007, 601, 68

13. Zhang, Q. T.; Tour, J. M. J. Am. Chem. Soc. 1998, 120, 5355-5362.

14. Tour, J. M.; Wu, R. Macromolecules 1992, 25, 1901-1907.

15. Hergué, N.; Mallet, C.; Frère, P.; Allain, M.; Roncali, J. Macromolecules 2009, 42, 5593-5599.

16. Hergué, N.; Frère, P. Org. Biomol. Chem. 2007, 5, 3442-3449.

17. Hergué, N.; Frère, P.; Roncali, J. Org. Biomol. Chem. 2011, 9, 588-595.

18. Hergué, N.; Mallet, C.; Touvron, J.; Allain, M.; Leriche, P.; Frère, P. Tetrahedron Lett. 2008, 49, 2425-2428.

19. Huddleston, P. R.; Barker, J. M. Synth. Commun. 1979, 9, 731-734.

20. Hagiwari, H.; Komatsubara, N.; Hoshi, T.; Suzuki, T.; Ando, M. Tetrahedron Lett. 1999, 40, 1523-1526.

21. Corral, C.; Lissavetzky, J. Synthesis 1984, 847-850. 
22. Compound 4a see Refs. 12 and 15.

Compound 4b: Colorless oil, ${ }^{1} \mathrm{H}$ NMR $\left(\mathrm{CDCl}_{3}\right) \delta(\mathrm{ppm}) 0.91\left(\mathrm{t}, 3 \mathrm{H},{ }^{3} \mathrm{~J}=7.1 \mathrm{~Hz}\right)$, $1.34(\mathrm{~m}, 4 \mathrm{H}), 1.44(\mathrm{~m}, 2 \mathrm{H}), 1.82(\mathrm{~m}, 2 \mathrm{H}), 3.98\left(\mathrm{t}, 2 \mathrm{H},{ }^{3} \mathrm{~J}=6.4 \mathrm{~Hz}\right), 6.21(\mathrm{~d}, 1 \mathrm{H}$, $\left.{ }^{4} \mathrm{~J}=3.5 \mathrm{~Hz}\right), 7.18\left(\mathrm{~d}, 1 \mathrm{H},{ }^{4} \mathrm{~J}=3.5 \mathrm{~Hz}\right) ;{ }^{13} \mathrm{C} \operatorname{NMR}\left(\mathrm{CDCl}_{3}\right) \delta(\mathrm{ppm}) 14.1,22.6,25.7$, 29.0, 31.6, 71.0, 97.1, 103.5, 121.9, 153.9; $\mathrm{m} / \mathrm{z}\left(\mathrm{M}^{+}\right)=262$; Elemental Anal. Calcd for $\mathrm{C}_{10} \mathrm{H}_{15} \mathrm{OBrS}$ : C, 45.63; $\mathrm{H}, 5.74$. Found: C, 45.37; $\mathrm{H}, 5.68$.

Compound 4c: Colorless oil, ${ }^{1} \mathrm{H}$ NMR $\left(\mathrm{CDCl}_{3}\right) \delta(\mathrm{ppm}) 0.99(\mathrm{~m}, 6 \mathrm{H}), 1.35-1.62$ $(\mathrm{m}, 8 \mathrm{H}), 1.82(\mathrm{~m}, 1 \mathrm{H}), 3.90\left(\mathrm{~d}, 2 \mathrm{H},{ }^{3} \mathrm{~J}=5.7 \mathrm{~Hz}\right), 6.22\left(\mathrm{~d}, 1 \mathrm{H},{ }^{4} \mathrm{~J}=3.6 \mathrm{~Hz}\right), 7.18(\mathrm{~d}$, $\left.1 \mathrm{H},{ }^{4} \mathrm{~J}=3.6 \mathrm{~Hz}\right) ;{ }^{13} \mathrm{C} \mathrm{NMR}\left(\mathrm{CDCl}_{3}\right) \delta(\mathrm{ppm}) 11.2,14.1,23.0,23.9,29.1,30.5,39.3$, 73.4, 96.9, 103.7, 121.8, 154.1; $m / z\left(\mathrm{M}^{+}\right)=291$. Elemental Anal. Calcd for $\mathrm{C}_{12} \mathrm{H}_{19} \mathrm{OBrS}$ : C, 49.49; $\mathrm{H}, 6.58$. Found: $\mathrm{C}, 49.75 ; \mathrm{H}, 6.35$.

23. Compound 5: Colorless oil, ${ }^{1} \mathrm{H}$ NMR $\left(\mathrm{CDCl}_{3}\right) \delta(\mathrm{ppm}) 0.38(\mathrm{~s}, 9 \mathrm{H}), 3.88(\mathrm{~s}, 3 \mathrm{H})$, $6.47(\mathrm{~s}, 1 \mathrm{H}) ; \mathrm{m} / \mathrm{z}\left(\mathrm{M}^{+}\right)=261$.

Compound 7: Beige solid, mp $140{ }^{\circ} \mathrm{C},{ }^{1} \mathrm{H}$ NMR $\left(\mathrm{CDCl}_{3}\right) \delta(\mathrm{ppm}) 0.41(\mathrm{~s}, 18 \mathrm{H})$, $3.90(\mathrm{~s}, 6 \mathrm{H}) ;{ }^{13} \mathrm{C}$ NMR $\left(\mathrm{CDCl}_{3}\right) \delta(\mathrm{ppm})-1.08,60.9,113.6,123.2,132.1,151.9$; MS (Maldi-Tof): $\mathrm{C}_{16} \mathrm{H}_{24} \mathrm{Br}_{2} \mathrm{O}_{2} \mathrm{~S}_{2} \mathrm{Si}_{2}$ calcd 527.9, 529.9, 525.9; found 527.4, 529.4, 525.4 .

Compound 8: Yellow pale solid, mp $142{ }^{\circ} \mathrm{C},{ }^{1} \mathrm{H}$ NMR $\left(\mathrm{CDCl}_{3}\right) \delta(\mathrm{ppm}) 3.91(\mathrm{~s}$, $6 \mathrm{H}), 7.15(\mathrm{~s}, 2 \mathrm{H}) ;{ }^{13} \mathrm{C} \mathrm{NMR}\left(\mathrm{CDCl}_{3}\right) \delta(\mathrm{ppm}) 61.0,106.3,119.3,120.8,150.2$; MS (Maldi-Tof): $\mathrm{C}_{10} \mathrm{H}_{8} \mathrm{Br}_{2} \mathrm{O}_{2} \mathrm{~S}_{2}$ calcd 383.8, 385.8, 381.8; found 383.2, 385.2, 381.2. Elemental Anal. Calcd for $\mathrm{C}_{10} \mathrm{H}_{8} \mathrm{O}_{2} \mathrm{Br}_{2} \mathrm{~S}_{2}$ : C, 31.27; $\mathrm{H}, 6.10$. Found: $\mathrm{C}, 31.31 ; \mathrm{H}$, 6.32 .

24. Compound 9: Yellow solid, mp $210-212{ }^{\circ} \mathrm{C}$ (dec.); ${ }^{1} \mathrm{H}$ NMR $\left(\mathrm{CDCl}_{3}\right) \delta$ (ppm) $3.91(\mathrm{~s}, 3 \mathrm{H}), 4.06(\mathrm{~s}, 3 \mathrm{H}) ;{ }^{13} \mathrm{C}$ NMR $\left(\mathrm{CDCl}_{3}\right) \delta(\mathrm{ppm}) 52.5,62.7,110.9,117.9$, 131.8, 158.5, 160.4; MS (Maldi-Tof): $\mathrm{C}_{14} \mathrm{H}_{12} \mathrm{Br}_{2} \mathrm{O}_{6} \mathrm{~S}_{2} \mathrm{M}-\mathrm{Br}$ calcd 420.9, 418.9, found $420.4,418.4$.
Compound 10: Beige solid, dec. from $150{ }^{\circ} \mathrm{C},{ }^{1} \mathrm{H}$ NMR $\left(\mathrm{CDCl}_{3}\right) \delta(\mathrm{ppm}) 3.91(\mathrm{~s}$, $6 \mathrm{H}), 6.40(\mathrm{~s}, 2 \mathrm{H}) ;{ }^{13} \mathrm{C} \mathrm{NMR}\left(\mathrm{CDCl}_{3}\right) \delta(\mathrm{ppm}) 57.7,98.2,105.3,128.5,154.4$; MS (Maldi-Tof): $\mathrm{C}_{10} \mathrm{H}_{8} \mathrm{Br}_{2} \mathrm{O}_{2} \mathrm{~S}_{2}$ calcd 383.8, 385.8, 381.8; found 383.3, 385.3, 381.3. 25. Leriche, P.; Frère, P.; Roncali, J. J. Mater. Chem. 2005, 15, 3473-3478.

26. Antolini, L.; Folli, U.; Goldoni, F.; Iarossi, D.; Mucci, A.; Schenetti, L. Acta Polymer. 1998, 49, 248-251.

27. X-ray single-crystal diffraction data were collected at $293 \mathrm{~K}$ on a BRUKERNONIUS KappaCCD diffractometer, equipped with a graphite monochromator utilizing MoK $\alpha$ radiation $(\lambda=0.71073 \AA)$. The structure was solved by direct methods using SIR92 (Altomare et al., 1993) and refined on $\mathrm{F}^{2}$ by full matrix least-squares techniques using SHELXL97 (G.M. Sheldrick, 1998). All non-H atoms were refined anisotropically and absorption was corrected by SADABS program (Sheldrick, Bruker, 2000). The $\mathrm{H}$ atoms were included in the calculation without refinement

Crystallographic data for 7: $\mathrm{C}_{16} \mathrm{H}_{24} \mathrm{Br}_{2} \mathrm{O}_{2} \mathrm{~S}_{2} \mathrm{Si}_{2}, M=528.47$, colorless plate, $0.30 \times 0.18 \times 0.05 \mathrm{~mm}^{3}$, monoclinic, space group $P 2 / n, a=10.0120(7) \AA$, $b=10.3625(5) \AA \quad c=11.2464(6) \AA \quad \beta=96.069(5)^{\circ}, \quad V=1160.3(1) \AA^{3}, \quad Z=2$, $\rho_{\text {calc }}=1.513 \mathrm{~g} / \mathrm{cm}^{3}, \quad \mu($ Mo K $\alpha)=3.783 \mathrm{~mm}^{-1}, \quad F\left(\begin{array}{ll}0 & 0\end{array}\right)=532, \quad \theta_{\min }=3.25^{\circ}$, $\theta_{\max }=30.00^{\circ}, 20,108$ reflections collected, 3369 unique $\left(R_{\text {int }}=0.08\right), 113$ parameters, $\mathrm{R}^{1}=0.0390$ and $\mathrm{wR}^{2}=0.0649$ using 1904 reflections with $I>2 \sigma(I), \quad \mathrm{R}^{1}=0.1075$ and $\mathrm{wR}^{2}=0.0785$ using all data, $\mathrm{GOF}=0.990$, $-0.464<\Delta \rho<0.453 \mathrm{e} \AA^{-3}$.

Crystallographic data excluding structure factors have been deposited with the Cambridge Crystallographic Data under reference CCDC 781722. 